\title{
SOME ASPECTS OF LEGAL WORK IN ADMINISTRATIVE AGENCIES
}

\author{
By Fritz Morstein Marx $\dagger$
}

It is a self-evident proposition that under "government of laws" the government lawyer is an indispensable element in the conduct of public administration. Adoption by Congress of the Administrative Procedure Act of $1946^{1}$ has made him still more indispensable. This act gives uniform application to formal prescriptions designed to govern both rule-making and adjudication on the part of administrative agencies. Although the act has had a mixed reception, ${ }^{2}$ its influence is likely to extend beyond the federal sphere by stimulating state legislation of a similar character. ${ }^{3}$ Surely the legal phase of the administrative process is not on the decline. It is rather reaching a new high.

While many of the practical implications of the Administrative Procedure Act may come to light only in the course of time, this paper is not intended to explore the intricacies and technicalities of the new law. Here we propose to concentrate on some of the general characteristics of legal work in the institutional context of public administration. The cardinal fact behind most of these characteristics is the necessity of linking responsibility for matters of law with responsibility for management and operations. Such fusion in responsibility is impossible to attain without close working relationships between gov-

$\dagger$ Staff Assistant, Office of the Director, Bureau of the Budget, Executive Office of the President; Lecturer on Political Science, American University; author of Comparative Administrative Law: The Continental Alternative, 91 U. of PA. L. REv. 118 (1942) ; Comparative Administrative Law: Exercise of Police Power, 90 U. oF PA. L. Rev. 266 (1942) ; Comparative Administrative Law: Economic Improvisation by $P u b$ lic Authorities, 88 U. OF PA. L. REv. 425 (1940) ; Comparative Administrative Laz: $A$ Note on Review of Discretion, 87 U. of PA. L. Rev. 954 (1939). The views expressed in this paper are those of the author speaking solely for himself; the topic is outside the range of his official concerns.

1. 60 STAT. 237, 5 U. S. C. A. $\$ \$ 1001-1011$ (Supp. 1946).

2. The expectations of the sponsors of the Administrative Procedure Act have been stated in several reports prepared in recent years under auspices of the American Bar Association; these reports have had wide circulation and need not be listed here. Other observers, especially students of public administration, have expressed the fear that the act may severely cramp the style of government regulation and public management. See Blachly and Oatman, Sabotage of the Administrative Process, 6 Puв. AnmIN. Rev. 213 (1946); Price, The Judicial Test in Elements of Public Administration 519, at 529 et seq. (Morstein Marx ed. 1946). There have also been suggestions to the effect that the act will lead to a measurable expansion of the legal staffs of federal agencies. In the words of a newspaper columnist specializing in the administrative side of public affairs, the act is becoming known as the "full employment act for lawyers." Kluttz, Federal Diary, Washington Post, October 31, 1946, p. 7, col. 1.

3. For some antecedents, see Current IDEas in State Legislatures, 1944-45, State Law Digest Report No. 8, 5-6 (Lib. of Cong., Leg. Ref. Ser. 1947). 
ernment lawyers and administrative officials. ${ }^{4}$ This pattern of cooperation is usually indicated more or less specifically in various arrangements embedded in departmental organization and procedure. It is also reflected in the customary statement regarding the location and principal functions of the departmental law office. Still more important, in many instances, for the measure of cooperation actually achieved is the mutual acceptance of a doctrine of working together.

The burden carried by legal staffs in the departmental system should not be underestimated. Nor is the breadth of their tasks unacknowledged. As a recent committee of inquiry has put it, "We have been forcibly impressed by the pervasive role played by the lawyer in the administration of the American Government. Every branch of the Federal Government proceeds under specific statutory authority, and every statute and every executive action is subject to the limitations of the Constitution. There inevitably arise a swarm of legal problems around every officer charged with administrative responsibility." "5 Or, in the words of a student of public administration, "... the lawyer has become an omnipresent and inescapable pillar of administrative counsel and decision." " Indeed, it is hardly an exaggeration to say that "the lawyer, in contrast with the ordinary professional employee of the Government, is inevitably thrown into the heart of the policy-making process and of necessity has an important, and often a controlling, voice in the major issues of his department or agency." 7 For it is law that governs all administrative policy.

Moreover, the scope of legal responsibility in administrative agencies is considerably wider than it should have to be, because of the profusion of internal controls that have become an almost traditional aspect of American public management. The combination of "government of laws" with a well-nigh categorical separation of powers has lent a great deal of encouragement to legislative enactment of checks and restraints intended to sharpen executive responsibility. This body of statutory control procedures is supplemented by numerous regulations emanating from central agencies which act as overseers of good government in such fields as personnel, budgeting, accounting, and auditing. The jurisprudence of the Comptroller General, to cite

4. Rule-making and adjudication form merely one segment of these relationships. By imposing rather rigid procedural requirements in these two areas, the Administrative Procedure Act tends to erect something of a formal barrier between government lawyers and administrative officials that does not exist in any other fields within the range of their cooperation. It may be doubted that this consequence is desirable, considering the need for instilling a strong sense of administrative legality in all of the activities of government agencies.

5. President's Committee on Civil Service Improvement, H. R. Mrsc. Doc. No. 118, 77th Cong., 1st Sess. 31 (1941).

6. Pfiffner, Public Administration 501 (Rev. ed. 1946).

7. President's Committee, supra note 5, at 31 . 
only one example, is in itself vast and complex enough to cause administrative officials to call for legal help. ${ }^{8}$ Operation of these elaborate controls is watched carefully, both by the legislature and the central agencies of the executive branch. Even good lawyers may easily run into trouble within so many barbed-wire fences. An example is furnished by the legislative advice a federal agency received of late during a congressional appropriation hearing. Said the committee chairman in an all but joking vein, "if necessary, we will put your counsel, who wrote this interpretation, in jail for violation of the anti-deficiency law, and you tell him so." 9

When we speak of legal work in administrative agencies, we should perhaps at the outset draw a clear line of demarcation with regard to that department which serves as a general legal agent for the executive branch as a whole-the Department of Justice. Obviously, this department occupies a particular place. In the federal government, the relation of departmental law officers to the Department of Justice has been described as "somewhat akin to the English division of the bar, whereby the solicitors work with the clients (in this case the executive departments or other agencies) and the barristers (here, the Department of Justice) deal with the courts." 10 Before World War II, about three-fourths of all lawyers in the employ of federal administration were to be found outside the Department of Justice. Both because the relationships between the executive branch and its main law department ${ }^{11}$ are of a distinct character and because the bulk of legal activity in government rests in the various administrative agencies, this discussion will focus on the place of the agency lawyer. And because we are not concerned primarily with those functions often called quasi-legislative and quasi-judicial, emphasis will be placed upon conditions prevailing in ordinary executive departments, rather than on those typical of the independent regulatory commissions and boards. As a consequence, the area to be examined will show much similarity to the range of factors that affect the manner of operation of legal staffs in large-scale private business organizations. The suggestions offered in the course of our discussion may therefore be equally pertifent in the fields of both private and public management.

One distinction between private and public management which exerts great influence upon the role of legal staffs lies in the degree to

8. For an interesting illustration, see Note, 15 Geo. WASH. L. REv. 349 (1947).

9. Hearings Before Senate Comnittee on Appropriations on $H . R .2849,80$ th Cong., 1st Sess. 26 (1947).

10. Cummings and McFardand, Federal Justice 490 (1937).

11. Selected references to the work of state and municipal law departments are given by Pfiffner, The Role of the Lawyer in Public Administration, 20 So. CALIF. L. REV. 37 (1946). 
which executive departments are under continuous scrutiny from the outside-by legislative committees, by individual lawmakers, by the press, by interest groups, and by central control agencies within the executive branch itself. Administrative officials must hence be able to adjust their intellectual and emotional processes to the peculiarities of "life in a goldfish bowl." 12 For one thing, living in a goldfish bowl multiplies the tendency inherent in all hierarchies to become preoccupied with avoiding mistakes at any price. ${ }^{13}$ For another, escape from mistakes easily resolves itself into a pathological search for concurrence on proposed action-and who would want to leave out the lawyer? The Administrative Procedure Act has done some brisk scrubbing of the goldfish bowl. Under the act, all federal agencies must account for the structure of authority, as well as the basic procedures they rely upon, in detailed statements published in the Federal Register. The resulting tome of almost one thousand closely printed pages of large format ${ }^{14}$ has the incidental effect of making a quick empirical survey of legal activities on the departmental level simpler than it used to be. We now can see even the smaller fish very clearly, and some things that aren't fish at all. ${ }^{15}$

In the matter of endowing the legal staff of an executive department with internal independence, ${ }^{16}$ the general drift of official opinion in federal administration appears to be rather in the opposite direction. Virtually all federal agencies describe the work of their lawyers as a staff activity closely tied into departmental management and operations.

12. For illuminating comments on the conditions of publicity in public administration suggested in this phrase, see Juran, Bureaucracy-A Challenge to Betrer Management (1944)

13. On these and other tendencies of the bureaucratic milieu, see Finer, Critics of "Bureancracy," 60 PoL. ScI. Q. 100 (1945).

14. This formidable compilation of materials is contained in No. 177, Pt. II, 11 FED. REG. (1946), hereafter cited simply as O \& P ; pagination for the entire Part II carries the prefix "177A". For a directory of principal law offices maintained by federal agencies, see Legal Divistons of Federal Departments and AgENCIEs, in UNITED States Government Manual (Supp. June 1946).

15. Two examples, selected at random, of "things that aren't fish at all" are taken from the descriptions dealing with the Library of Congress and the National Archives. The former contains the following provision: "\$300.109 Music Division. Under the administration of a Chief, the Music Division is responsible for the custody and service of the collections of music and the literature of music. The Division provides a reference service concerning music in response to inquiries whether received in person, by telephone, or by mail ; maintains a service to readers in the Music Reading Room; plans and superintends the performance of public concerts; supervises the operations of the Folklore Section, including the Archive of American Folk Song, and the Recording Laboratory; and prepares special bibliographies, guides, indexes and publications appropriate to its service." O \& P 177A-586. The description of the National Archives includes this statement: "\$1.3(e) (2) Division of Cleaning and Rehabilitation. Is responsible for cleaning and fumigating records and library materials and for unfolding, flattening, laminating and repairing records in the custody of the Archivist." $O \& P$ $177 \mathrm{~A}-600$. et seq.

16. For a discussion of the merits of this issue, see Pfiffner, supra note 11 , at 46 
This view is also shared in other quarters. ${ }^{17}$ While admittedly descriptions of organization and definitions of functions are not the most dependable guide to administrative realities, ${ }^{18}$ the fundamental tenor of official statements, notwithstanding many variations, is remarkably explicit in asserting the staff character of legal work.

Occasionally the staff role of the departmental law office is stated in express terms. Thus, the Office of the Solicitor in the Department of Agriculture "functions as a staff agency." 19 In the same manner, the Office of General Counsel of the (now defunct) Civilian Production Administration was described as a "staff office." 20 In other instances the staff character of the law office is indicated in the way its functions are outlined. As one illustration, in the Federal Deposit Insurance Corporation, "the Legal Division, headed by a General Counsel, advises and assists the board of directors and the several Divisions of the Corporation, with respect to all legal matters concerning the functions, activities, and operations of the Corporation, including all litigation, correspondence of a legal or quasi-legal character, interpretation of organic law and Federal and State laws applicable to or affecting the Corporation or its activities, and the preparation of rules, regulations, orders, and opinions, and documents

17. See, for instance, PFIFfNer, op. cit. supra note 6 , at 501 et seq.; Morstein Marx, The Laroyer's Role in Public Administration, 55 Y ALE L. J. 498 (1946) ; Pfiffner, supra note 11, at 53 et seq.

18. In the early history of the Office of Price Administration, for example, official pronouncements would have helped little in determining to what extent the legal functions performed within the agency bore a true staff relationship to its management and operations. The marked shift that occurred later is probably best indicated by a comparison of the revised Administrative Order No. 79 on Organization of the Legal Functions (Sept. 14, 1943) with Leventhal, Function of the Price Lawyer in the Office of Price Administration in A Manual of PrICE Control 280 et seq. (O. P. A. 1943).

19. To quote the full provision, "\$2208.1 Central office and organization-(a) The Solicitor. The Solicitor is the legal counsel for the Department and the legal adviser of the Secretary, in accordance with the requirements of the Act of May 26, 1910 (5 U. S. C. 518). The office functions as a staff agency. The Solicitor is assisted by several Associate Solicitors, who supervise specific phases of the work of the office as assigned through divisions each of which is headed by a Chief, and an Associate Solicitor on Litigation." O \&, P 177A-301.

20. The text of the provision reads as follows: "\$903.203 Office of the General Counsel. As a staff office of the Civilian Production Administration, the Office of General Counsel advises the officials of CPA in all matters involving questions of law as they relate to the present and proposed activities of the entire organization, including relations with other Government agencies. As part of this general responsibility, the Office performs a number of duties. Its staff drafts all proposed orders and regulations and prepares interpretations of regulations and orders issued by CPA in the manner prescribed in CPA Regulation 3. The Office of General Counsel exercises legal supervision over the formation and functioning of Industry Advisory Committees. The Office also supervises the legal aspects of the compliance activities of CPA designed to secure enforcement of the orders and regulations issued by the Administration. In this connection the legal staff participates in investigations and administrative hearings, drafts, charging letters, and orders, and recommends civil or criminal action to the Department of Justice, collaborating in such action with officials of that Department. The Office has regional attorneys who service the field offices. In addition, the Office is responsible for legislative matters in which the Agency is concerned." $O$ \& $P$ $177 \mathrm{~A}-373$. 
of a legal character." 21 Language such as this amounts to a fairly precise elaboration of the staff idea.

Practically the same effect is achieved by official reference to the activities of departmental law offices as advisory in nature. The consultative function of the chief legal officer and his staff is also made evident in his frequent designation as "general counsel." 22 It is interesting to notice, however, how much variety exists among federal agencies in the job descriptions they have evolved to identify the work of their law offices. The differences catch the eye, even though upon examination they reduce themselves for the most part to matters of verbiage rather than of facts.

For example, sometimes the chief law officer's contribution to the development of departmental policy and programs is specifically underscored. ${ }^{23}$ Sometimes his responsibility for legal clearance of administrative regulations, procedures, and orders has found special mention. ${ }^{24}$ Sometimes, also, stress is laid on his responsibility "for all legal

21. O \& P 177A-432. Similar statements-for the Department of Commerce and the Federal Reserve System, respectively-are the following: " $\$ 11.2$ Office of the Solicitor. The Solicitor is the chief law officer of the Department of Commerce. As such, he acts as legal adviser to the Secretary of Commerce, the Under Secretary, the Assistant Secretary, and the chiefs of the various bureaus." O \& $P 177 \mathrm{~A}-302$. "\$261.3(b) Legal Division. The Legal Division is headed by the Board's General Counsel. It advises and assists the Board with respect to legal matters, including, among other things, litigation, and preparation of, or assistance on, regulations, orders, opinions and other documents or correspondence of legal or semi-legal character." O \& P 177A-509.

22. Statistically speaking, the increasing frequency of this designation of the chief legal officer on the departmental level of federal administration is pushing the equally respectable but more traditional title of "solicitor" into the background.

23. An example is offered by the National Housing Agency, which has this to say: "\$ 751.3 Office of the General Counsel. The General Counsel is responsible to the Administrator-Expediter and is the main legal officer within the Agency. The Office of the General Counsel is responsible in general for providing all legal counsel and assistance involved in the formulation and development of the Agency's policy and program and in the performance of the responsibilities assigned to the Central Office Staff; for formulating and recommending to the Administrator-Expediter a program and procedures to assure compliance with the public regulations and directives involved in the execution of the Agency's program; and the interpretation of all public regulations, orders and directions of the Agency and of the legislation under which the Agency operates. The Office of the General Counsel is also responsible for establishing policies, standards, and procedures to guide the legal activities in the Regional Offices and to assure uniformity of legal interpretations, practices and procedures in the Regional Offices; and for representing the Agency on legislation, public regulations, litigation, and other legal matters." O \& P 177A-858.

24. An illustration is furnished by the War Assets Administration, which presents the following description: "\$ 8401.7 Office of the General Contusel. The Office of the General Counsel advises the Administrator and the offices and divisions of the War Assets Administration on all legal and legislative matters arising out of the conduct of the work of the Administration and determines, prior to adoption, that all regulations, procedures, orders, and methods are legally sound and in accord with the legal intent of legislation and orders governing War Assets Administration operations. The authority to perform such functions is assigned to the General Counsel, who is authorized to redelegate to subordinate officials such part of that authority as he deems necessary." O \& P 177A-751. The reader will notice that the General Counsel's responsibility for legal clearance also extends to "methods." Even if one were to construe this term quite narrowly and in relation to procedural matters, inclusion of matters of method in the clearance clause is a revealing indication of the flowering of legal review in federal administration. 
activities" of his agency. ${ }^{25}$ Finally, in a number of agency statements there appears an inclination to weave into the general description of the departmental law office some particular aspects incidental to its main concerns. The chief legal officer may be declared "responsible" for substantive policies of one kind or another, ${ }^{26}$ or for the disposition of statutory appeals, ${ }^{27}$ or for a long list of kinds of administrative business having legal implications. ${ }^{28}$ Perhaps what we need is less originality and more uniformity in defining the mission of the departmental law office.

Although the staff role of the chief legal officer in the federal agencies is generally stated in explicit or implicit terms, occasionally a law office carries along special functions that are more in the nature

25. This phrase occurs, for instance, in the description of the Federal Security Agency: "\$1.3 Office of the General Counsel. The Office of the General Counsel is under the direction and control of the General Counsel. It renders legal advice to the Administrator, to the Staff Offices and Operating Branches of the Agency and to the heads thereof, and is responsible for all legal activities of the Agency. It represents the Agency in litigation when direct representation is authorized by law and maintains liaison with other Government agencies and establishments in legal matters. The Office of the General Counsel is composed of a departmental staff located in Washington, D. C., and Baltimore, Maryland, a division in New York, New York, to service the Bureau of Employees' Compensation and a regional staff under the direction of regional attorneys. . . " O \& P 177A-519. Of course, as the wording of the statement as a whole makes quite clear, the responsibility of the General Counsel's Office "for all legal activities of the Agency" is not intended as a claim to institutional autonomy, but merely as a delineation of the subject-matter area encompassed by its advisory role.

26. An illustration is supplied by the description of the Department of the Interior, which contains the following statement: "\$01.12 Solicitor . . . The Solicitor is responsible for patent policies and procedures within the Department, and for the administrative adjustment of tort claims under the Federal Tort Claims Act. See 43 CFR $4.20,4.21, . . . \mathrm{O} \& \mathrm{P} 177 \mathrm{~A}-191$. The patent policies and procedures here referred to relate presumably to the function of the Bureau of Land Management to issue land patents. Obviously, in discharging his responsibility in this respect, the Solicitor cannot be assumed to operate as final authority, but as a source of recommendations to the policy-determining officials at the helm of the Department.

27. A case in point is presented in the description of the Civil Service Commission, which says: "\$ 60.5 Chief Law Officer... He adjudicates appeals of veteran preference eligibles that are filed under the Veterans Preference Act of 1944." O \& P 177A-362. Again, while suggestive of other conclusions, the sentence dealing with the adjudication of appeals does not minimize in any way the final responsibility of the Civil Service Commission. The Chief Law Officer assists the Commission in the exercise of this responsibility.

28. For instance, the description of the Post Office Department contains the following provision: " $\$ 1.4(\mathrm{~g})$ Solicitor ... (4) The Solicitor is charged . . . with the determining of questions as to the delivery of mail the ownership of which is in dispute; with the consideration of cases relating to lotteries and the misuse of the mails in furtherance of schemes to defraud the public; with the consideration of all questions relating to the mailability of alleged indecent, obscene, scurrilous, or defamatory matter; with determining the legal acceptability of securities offered by banks to secure postal savings deposits; with the examining and, when necessary, drafting of all contracts of the department; with the handling of cases arising from the application of the private express statutes (Government monopoly of carrying letters); with the legal work incident to the enforcement of those provisions of the espionage law which concern the Post Office Department; with the consideration of alleged extortion letters; with the receipt of suggestions for changes in the Postal Laws and Regulations; editing of all proposed amendments and with the responsibility of seeing that the Postal Laws and Regulations are amended in accordance with legislation; and with such other like duties as may from time to time be required by the Postmaster General." O \& P 177A-115. 
of line operations. On grounds of logic, this may be an incongruous arrangement. On grounds of practicality, much may be said in favor of lodging in the law office particular services whose operations are intertwined with legal considerations. An example is found in the location of the Guardianship Service of the Veterans Administration in the Office of the Solicitor. ${ }^{29}$ A certain degree of duality of purpose in the departmental law office also arises from the independent status of trial examiners. ${ }^{30}$ In a category by itself belong the fairly exceptional cases where the chief legal officer of a department exercises powers conferred upon him directly by statute. Thus, in the Treasury Department, "although the chief function of the General Counsel is to give legal advice and assistance to the administrative officers of the Department, numerous duties and powers, some of them seldom exercised,

29. The relevant part of the provision dealing with the Solicitor's Office reads as follows: "\$01.4 Organization of Office of Solictor. (a) The Solicitor is the adviser to the Administrator, staff members and heads of operative agencies on all legal matters, and is responsible for the conduct of the activities set forth herein. (b) The Office of Solicitor will consist of the Executive Office, the Legal Service, and the Guardianship Service, the heads of which will be responsible to the Solicitor and will include a Deputy Solicitor and legal representatives detailed to the operating services. . . (f) The Legal Service under an Associate Solicitor, will conduct the following functions: (1) Rendering opinions on all legal matters presented to the Solicitor; (2) Preparation or approval of submissions to the Attorney General and Comptroller General; (3) Final disposition of claims for damages, and other claims arising through the operation of Veterans Administration activities; (4) Cooperation with the Department of Justice in civil litigation involving either the Veterans Administration or its officials in their official capacity, and in criminal actions arising under veterans laws; (5) Recognition, suspension or disbarment of attorneys or agents practicing before the Veterans Administration; (6) Technical supervision of legal work of Assistant Solicitors in the branch office, and through them the legal and litigation - other than guardianship-responsibilities of the field offices. (g) The Guardianship Service, under an Associate Solicitor, will conduct the following functions: (1) General policy and technical direction of all guardianship affairs of the Veterans Administration, including litigation in the State Courts, guardianship matters in the foreign countries and the insular and territorial possessions of the United States, and cooperation with the Department of Justice in claims arising in guardianship cases: (2) Technical supervision of guardianship supervisory functions of Assistant Solicitor's offices; (3) Through the Assistant Solicitors: (i) Technical supervision and training of field examiners; (ii) Technical supervision of all guardianship functions of Offices of Chief Attorneys ; (4) Correlation of State legislation affecting Veterans Administration." O \& P 177A-932.

30. An illustration of this kind of internal independence-antedating the Administrative Procedure Act of 1946-is offered in the description of the Department of Labor, which contains the following provision: "\$2.002 Office of the Solicitor-(a) Functions. The Solicitor serves as legal adviser to the Secretary of Labor. The branches and the other operating units carrying out the functions of the Solicitor are as follows: ... (4) The Legislative and Trial Examining Branch. The Legislative and Trial Examining Branch includes the Trial Examining Section which consists of trial examiners who, at the designation and direction of the Secretary in specific cases, preside over administrative hearings and recommend decisions in proceedings based on complaints of violation of contracts subject to the Walsh-Healey Public Contracts Act. In the performance of these functions they act independently, subject to the requirement that they comply with the precedents and policies of the Department under the act. They are available also to preside over any other hearings authorized to be conducted by the Secretary or by bureaus, offices and other agencies in the Department. The Legislation and Bureau Service Section prepares advisory letters in response to inquiries from members of the public with respect to labor laws with which the Department is concerned. . . O \& P 177A-340. 
are vested in him by statute, Executive order, or otherwise." 31 Taken literally, some of these powers, if exercised independently, would place the General Counsel in quite an anomalous position toward the Secretary of the Treasury.

In summing up this brief review of the way in which federal administrative agencies define the tasks they expect their law offices to fulfill, we may say that in the composite picture the chief legal officer is presented as a staff agent. As the next step in our inquiry, it will be desirable to consider the matrix of relationships in which he aims to discharge his functions as a staff agent. There is no need here for attempting any hair-splitting in the identification of the staff function. It will be more profitable to suggest its essence in showing with reasonable precision what staff work actually entails.

\section{II}

As might be expected, administrative staff organization has been influenced by the military prototype of the General Staff. Yet, in many respects, the development in the civilian area has followed a separate course. What is perhaps most important, the administrative staff concept has evolved in close connection with the immediate needs of management, both in business and in government. The movement for the promotion of scientific management seized upon the staff idea principally for its possibilities in invigorating and refining the managerial process. ${ }^{32}$

Unfortunately, the emerging specialist in management analysis has not always demonstrated sufficient acumen in sifting the essential features of civilian staff organization from mere marginal embellishments. Although there is no dearth of technical writing on the subject, precisely what factors make for good staff work is a question

31. O \& P 177A-8. These authorizations directly addressed to the Treasury Department's General Counsel are enumerated in the following provision: "\$ 1.4 General Connsel. . . . In certain instances of absence or sickness of other officials, he is authorized to act as Secretary of the Treasury pursuant to 5 U. S. C. 4, 6, Executive Order No. 8714, March 18, 1941, 6 F. R. 1517, and Department Circular No. 224, July 15, 1943. The recommendation of the General Counsel if necessary to enable the Secretary of the Treasury to compromise claims in favor of the United States (31 U. S. C., Supp. V, 194; 19 U. S. C. 1617). Sureties on certain official bonds must be approved by him ( 5 U. S. C. 44,$520 ; 26$ U. S. C. $3943 ; 31$ U. S. C. 475 ). It is the duty of the General Counsel to exercise a general supervision over measures for the prevention and detection of frauds upon the revenue (5 U. S. C. 326); to issue warrants of distress against delinquent disbursing officers and receivers of public money (31 U. S. C. 506, 514); and to perform specified duties relative to the collection of revenues and debts due the United States (5 U. S. C. 323-325, 327, 328). The General Counsel is authorized to appoint agents to purchase lands sold on execution by the United States (31 U. S. C. 195); to control, rent, or sell lands or other property acquired in payment of certain debts (40 U. S. C. 301, 302); and to release real estate to a debtor upon payment of the debt to the United States (40 U. S. C. 306)." Id.

32. A convenient source of information may be found in 1 URWICK AND BRECH (eds.), The Making of Scientrfic Management (1945). 
none too frequently answered. Unfortunately, too, the findings of the specialist more often than not have remained enshrouded in his professional lingo. Administration, public and private, like "every branch of knowledge, every twig almost, has its own peculiar jargon-a mongrel vocabulary intended as convenient shorthand but usually achieving little more in practice than obscurity and chaos." ${ }^{33}$ Let us see whether we can stay close to the heart of the matter and at the same time avoid the befuddling vocabulary of the expert in something or other.

To start with the obvious, staff work may assume entirely different forms depending on its locus. The military General Staff, for instance, is most closely associated with planning in the sense of planmaking. To quote an official source, the General Staff of the War Department "is specifically charged with the duty of providing broad basic policies and plans that will enable the Commanding Generals of the Army Air Forces and the Army Ground Forces, task forces, theaters of operations, overseas and other commands, and the heads of the administrative and technical services to prepare and execute detailed programs." 34 On the other hand, as a simultaneous task, the General Staff "coordinates the development and the operation of the Army as a well-balanced, efficient fighting team." 35 As part of the latter duty, the six General Staff Divisions are expected to take an active share in the direction and supervision of all military business-assisting the Chief of Staff "in getting things done." 36

Differentiation among types of staff activity is carried still further. The assistance rendered by the General Staff in the exercise of directive power, though theoretically quite dissimilar to working out broad plans and "policy-making on an Army-wide level," 37 is officially distinguished from the business of the War Department Special Staff. The ten Special Staff Divisions, ranging from public relations to budgeting, ${ }^{38}$ are brought into a common grouping under the Deputy Chief of Staff "because of their fields of activity." ${ }^{39}$ Again, the Special Staff is set apart from both the technical and the administrative services of the War Department. As head of one of

33. 148 The Economist 370 (March 24, 1945).

34. UNITEd States Government Manual 182 (1st ed. 1947). The National Security Act, Pub. L. 253, 80th Cong., 1st Sess. (July 26, 1947) has changed departmental designations but not the differentiation of staff tasks here discussed.

35. Ibid.

36. WAR DePt. CIRc. No. 138, 6 (May 14, 1946).

37. Ibid.

38. Id. at 9. The position of the Budget Division as an element of the War Department Special Staff contrasts with the program-planning role which in the United States has come to be associated with the budget function in civilian staff organization in government.

39. Ibid. 
the administrative services, the Judge Advocate General, notwithstanding his position as "the chief law officer of the War Department and the chief legal adviser of the Secretary of War, the War Department, and the Military Establishment," ${ }^{40}$ is organizationally outside the Special Staff as well as the General Staff.

Like the heads of the other administrative services, however, being designated to act "also" as an "administrative staff officer of the War Department," ${ }^{41}$ the Judge Advocate General combines in himself "functions of staff and command." 42 The two functions, though combined in one and the same officer, are to be regarded as "separate and distinct in that each involves different responsibilities and duties, and the exercise of one is not to be confused nor permitted to interfere with the exercise of the other." 43

By contrast with the military sphere, civilian staff organization for administrative purposes has neither given so much weight to the plan-making function typified by the General Staff nor produced a commonly accepted nomenclature of staff activity. With few exceptions, administrative staff units simultaneously conform in part with the general staff concept, and in part with the special staff concept. Moreover, in these units the staff function usually appears in company with certain directive or operating responsibilities. Judging by the evidence examined earlier, ${ }^{44}$ one may safely conclude that the departmental law office does not in this respect depart from the general rule. Its place in the department and its general assignment is influenced by the conditions under which civilian staff organization originally came into being.

Historically, in the United States the staff idea in administrative organization was not simply borrowed from military usage. It was brought to the fore as a result of widespread efforts-in business enterprise as well as public administration-to achieve a higher degree of effectiveness in the general conduct of management. In government especially, the steady expansion of departmental functions and services, without a corresponding strengthening of the directive facilities of the chief executive, eventually approached a state of administrative irresponsibility. Constitutionally intended to be under unified control, the executive branch seemed to be in danger of dissolving itself

40. United States Government Manual 185 (1st ed. 1947).

41. WAR Departanent Circ., supra note 36, at 10.

42. $I d$. at 11 .

43. Ibid. For an extensive discussion of the growth and mission of the General Staff, see Nelson, National Security and THE General Staff (1946). A short survey of different military staff types is offered by Pence and Brownell, Types of Staff Organization Found in the United States Military Forces, 25 MIL. REv. 34 (Oct. 1945).

44. See Part I supra. 
into a multitude of self-centered agencies, each going its own way. The relative dormancy of executive superintendence in federal administration ended only when-in the wake of such strong figures in the presidency as Theodore Roosevelt and Woodrow Wilson-the Budget and Accounting Act of $1921^{45}$ provided in the Bureau of the Budget the beginnings of a presidential staff organization. Budgeting, as an administrative method of formulating annually a proposed work plan for the government as a whole, not only requires evaluation and integration of departmental programs but also leads directly into study of organization and management. Of these implications of preparing the executive budget the founders of the national budget system were keenly conscious. ${ }^{46}$ As the President's Committee on Administrative Management, some fifteen years later, was able to demonstrate persuasively, ${ }^{47}$ a straight line of organic growth runs from the establishment of the Budget Bureau to the kind of amplified staff organization formed in 1939, on the basis of the committee's proposals, as the Executive Office of the President. ${ }^{48}$

"The real powers of an executive are found in what he can do, which may be either less or more than those which the legalists declare him to possess." 49 The staff organization of the chief executive, inaugurated not only on the national level but also in many state and local governments by attaching to him the budget agency, has enabled him to accomplish more, especially in responsible use of his directive power, than even the most gifted administrative genius could hope to do singly. But the budget function, though a manner of planning, does not consummate itself in evolving plans in General Staff style. It is drawn closely into the central processes of executive management and control. And its exercise, not only in budget-making but also in the administration of the budget as sanctioned by the legislature, carries with it a constant trickle of general instructions and individual determinations coming down to the departments in the name of the chief executive. These several aspects have tended to become common characteristics of administrative staff work, centrally and in the various departments as well.. ${ }^{50}$

45. 42 STAT. 20 (1921), 31 U. S. C. $\$ 1$ (1940).

46. For the legislative motivations underlying the Budget and Accounting Act and for the institutional growth of the Budget Bureau, see Morstein Marx, The Burean of the Buldget: Its Evolution and Present Role, 39 Arr. PoL. Scr. Rev. 653,869 (1945).

47. Cf. President's Cominittee on Administrative Mianagement, Report with Spectal Studies (1937).

48. Cf. Brownlow and others, The Executive Office of the President: A Sympositm, 1 PUB. AdMr. Rev. 101 (1941); Morstein MarX (ed.), Federal Executive Reorganization Re-Exantined: A Symposinm, 40 AM. PoL. Scr. Rev. 1124 (1946).

49. See Coons, Management's Professional Responsibilities, 11 Advanced MaNAGEAIENT 142, 143 (1946).

50. Cf. Stone, Federal Administrative Management 1932-1942, 65 Transact. Am. Soc. of MeCH. ENG. 242 (1943). 
The core of administrative staff work, then, is not so much what is usually called planning as furnishing assistance to the administrator in his exercise of the executive function. ${ }^{51}$ The nature of this assistance, in turn, is adequately conveyed in three words: information, analysis, recommendation. Ideally, through his staff organization the administrator should have at his personal disposal all the knowledge, thought, and skill available in his department-insofar as it bears on his executive responsibilities.

Information must include the knowledge that accrues in each of the activities of the entire department. It must be guided through a system of filters so that only the data significant to the administrator move up to him, yet without loss of any item having such significance. Analysis both organizes and weighs the data, checking one set of data against another and in this way relating different data to one another so that meanings become clear, perspectives open up, and inferences grow specific. Recommendation thus flows from putting the whole picture in focus. It is the means of marking out the targets of action in their proper relationship, and of outlining the most appropriate method of action-considering the best knowledge and the best conjecture. From this angle, one of the essentials of administrative staff work is continuous awareness of the wider context of each proposition demanding attention. All staff work should be dominated by what Mr. Justice Cardozo used to speak of as the "totality view."

Such a "totality view" will arise in the individual member of an administrative staff organization in part as a matter of indoctrination, training, experience, and habit. A still more important factor is structural form. More than three generations ago, Attorney General Caleb Cushing observed with great insight that "want of due arrangement of public functionaries and their functions is want of due responsibility to society and to the law." 52 Want of "due arrangement" in the structure of an administrative staff organization all too often means want of effective staff work. When the chiefs of the individual staff units, in their relations with the administrator, operate as free entrepreneurs, each mindful only of his "jurisdiction" and its unchallengeable priority; when they are happiest in dealing with him singly; when their working contacts among one another are reduced to a polite minimum, with consultation formalized as a ritual of written

51. This, incidentally, is not at variance with military doctrine. The Staff Officers' Field Manual of the United States Army defines the staff in these words: "The staff of a unit consists of the officers who assist the commander in his exercise of command." Cf. Webb, The United States General Staff, Its Evolution: An Epitome, 26 Min. Rev. 33 (Nov. 1946). For the civilian side, see Millett, Working Concepts of Organization, in Elements of Public Administration (Morstein Marx ed. 1946) 140, at 145 et seq.

52. Cited by Cummings and McFarland, op. cit. supra note 10, at 498. 
exchanges-under conditions like these there is little chance for the administrator to have any true staff support. His staff is simply not organized.

We should not be thinking, of course, of organization charts with their air of unabashed finality, or of reporting relationships as stated solemnly in administrative manuals, or of the allocation of space around the administrator's office. How much the chiefs of the staff units work and think as one body does not depend on any of these factors, but is affected decisively by the preference of the administrator. In the last analysis, he is the organizer of his staff. If he appreciates that "function is the arbiter of organizational forms," 53 and that comprehension of every problem in its wider setting is the key to good staff work, he is likely to insist that the chiefs of the staff units spend enough time with him as a group. Only by achieving something of a collective mind can reasonable completeness of staff work be secured. Only when the participants, whether in staff conference or behind their own desks, regard themselves as one nucleus, can one talk of effective staff organization.

\section{III}

To express it differently, the question of structure in administrative staff work resolves itself primarily into the way in which staff members function in unity. The appropriate method of operating cannot be decreed. While the administrator, in acting on his preference, does much to outline the manner in which his staff organization functions, his is not the only formative influence. In the long run, staff organization must be sustained by the positive contribution that each participant is able to make toward successful group activity. One of the distinguishing marks of an effective staff officer is his sensitive awareness of the degree to which his own conduct strengthens or weakens the vitality of the staff nucleus.

As a professional soldier has recently pointed out, "It is much easier for an officer to act in any situation, and especially in an emergency, if his combat judgment is built on the application of doctrines which have been well learned and with which he is intimately familiar." 54 What applies to combat experience is true to no less an extent of staff activity. One must therefore regret that staff doctrine in the realm of administrative organization has suffered from neglect. There is little in the nature of organized knowledge presented

53. Macmafion, Memorandum on the Postwar International Information Progran of the United States 115 (1945). 1947).

54. Lt. Gen. McLain, Intangible Factors in Combat, 26 MrL. Rev. 1, 3 (March, 
in such a way that it can be readily utilized in training for staff duty. In such areas where administrative staff work appears to flourish, it is more frequently the result of an exceptionally constructive interplay of personalities than of a firmly implanted and widely shared concept or theory. In view of the dearth of articulate doctrine, every member of an administrative staff organization should always be conscious of the need for making himself a consistent embodiment of the staff idea. In all of his doings he should attempt to be a continuously active factor in building the staff group into the most efficient vehicle of its purpose.

To this extent, then, the individual staff officers-no less than the administrator himself-must play their parts in keeping the staff organization fully operative. All of them should be alert to detect and eliminate any tendencies that may destroy the cohesiveness of the group as an indivisible organ of joint planning. Should the administrator, for one reason or another, come to use any one staff officer increasingly as an independent source of personal counsel, an intelligent staff officer would know of ways and means to discourage his superior without becoming obnoxious. It will be possible, for instance, to suggest the advantages of broadening the basis of advice by calling in others. It is often easy to point out that more than one member of the staff organization is in various ways concerned with the subject under discussion.

As a very minimum, the staff officer "seen too often" by the administrator will take pains to post his colleagues on the topics that have been brought up in the administrator's office. Thus he may reinforce his own mind by tapping the ideas that have occurred to his colleagues. And at the same time he gives them their cue for making the administrator see that their own judgment will assist in reaching a considered decision. One thing, perhaps, need not be mentioned-that staff organization and prima donna ambitions are incompatible with each other.

In bringing the whole of a department's information and experience to bear upon a particular subject, in readjusting acknowledged goals and habitual means to novel situations, in reconciling differences of opinion that have survived analysis-in all of these phases of administrative staff work, direct contact between the administrator and the entire staff group offers great benefits. ${ }^{55}$ Direct contact among them and full consideration of the issue on the agenda avoid the ambiguities and the trickery of the written word. In the staff con-

55. This point has been made with great force by Folletr, Dynamic AdMinistraTION 297 (Metcalf and Urwick ed. 1942). 
ference, as a council of institutional thought, varying shades of firmness and of hesitation in the establishment of points of view are quickly disclosed by free discussion. As a man eminently qualified to judge in this matter has observed, "Attempts at covering up gaps in his information by more or less hazardous guesses have rightly undermined many a staff man's reputation for reliability." 56 When individuals, inspired by reasonable confidence in one another, jointly probe into a great many problems, there is much less inclination for the administrator to expect his staff members to know everything and for his staff members to shudder at the thought of conceding the possibility of something they do not know. ${ }^{57}$

To be sure, when seated around the conference table, the members of the staff organization concentrate in the main on the beginning and the closing phases of the staff job. They will reach agreements expeditiously on work still to be done as they pool their knowledge of things that demand attention; as they think ahead regarding issues likely to arise in the future; and as they reflect on the points of strength or of weakness in the scheme of departmental operations. In functioning as a group, they are equally effective in making up their minds on the merits of proposed solutions to problems that have been examined in some part of the staff organization. Between these two polessettling upon the order of staff business and coming to final terms on recommendations resulting from study-there is, of course, a vast area of staff activity. It divides itself into the much more timeconsuming tasks of investigation and analysis-desk jobs which for the most part fall to the rank and file within the several staff units.

Investigation and analysis, in the sense of organized projects, do not lend themselves to the kind of group action here sketched out. The group process is superior to individual determination as a device for establishing the general frame of reference within which various staff projects can be specifically defined in relation to one another. It is also a highly effective means of providing the practical equivalent of a reviewing board to test emerging proposals, fitting each into the realities of policy and operations. Use of the staff organization as a conference group to take an active part in determining the pattern of staff assignments and to integrate staff recommendations adds substantially to the sense of direction and of unity without which there can be no "totality view."

56. Goldenweiser, Research and Policy, 30 FEd. Res. Buri. 312, 317 (April, 1944).

57. The opposite attitudes are not uncommon when staff organization approximates a mere assortment of "jurisdictions" in the sense of exclusive fields of concern. The likelihood of such attitudes is increased when too much reliance is placed on written communication or when both the administrator and the individual staff member are without the self-educative influence of group discussion. 
The conference method puts a premium on ability to explain. ${ }^{58}$ In contrast with mere pondering, the act of explanation in itself compels a sorting of reasons and a discarding of points that do not seem to have enough strength to stand. The discipline of the explaining process is sharpened if the listeners are an audience of peers, ready to take apart whatever does not make sense. Moreover, the intimacy of personal relations that develops in a staff organization accustomed to operating as a group promotes a spirit of straight-forward inquiry that results in a high mortality rate for mere rationalizations. As each member of the group grows increasingly familiar with such prejudices and idiosyncracies as become conspicuous, discussion is correspondingly less likely to depart for any length from the general level of objectivity.

In coping with questions of administrative policy and management, conclusions flowing from analysis of data can seldom be dissociated completely from some element of conjecture. One may suspect that conjecture has still greater potentialities of misleading man's mind than even conclusions inadequately grounded on facts. Again, the group process of combined thought offers a substantial check preventing conjecture from running wild. This applies especially to the impact of purely subjective tendencies-the degree to which an individual is influenced at particular times "by fearful apprehension or by wishful thinking." 58 Unconstrained group discussion is good therapy for emotional tensions that otherwise might sway a man's professional judgment-a therapeutic effect that results painlessly from simply bringing such tensions "into the open." 60 It should perhaps be stressed that there is no conflict between the requirements of good staff work and occasionally proceeding on intelligent hunches where careful analysis fails to add up to more than a pretty good hunch. But it is exceedingly important that the staff group as a whole give searching thought to the assumptions that appear to support the hunch.

As in the process of coordination the elements to be coordinated themselves change to some extent, ${ }^{81}$ so what crystallizes as the "sense" of the staff meeting ordinarily incorporates more than is present in any particular recommendation coming up for consideration. The group process makes for a better balanced judgment, a more complete synthesis, a better rounded product. The "atmosphere" 62 of the meeting has a peculiar way of asserting itself. At the same time, the

58. The significance of this fact was recognized clearly by Folletr, op. cit. supra note 55 , at 175 .

59. Goldenweiser, supra note 56, at 316 .

60. FolletT, op. cit. supra note 55 , at 38 .

61. Id. at 200 .

62. Goldenweiser, supra note 56 , at 317 . 
group process exerts a policing influence. There is less peril for any member of the group unconsciously to become a victim of his "vested interest in an opinion previously expressed"- "as dangerous in a staff man as vested property interests are in a judge or legislator." ${ }^{83}$ Moreover, face to face with his colleagues, a staff officer will show better resistance against the temptation of going to undue extremes of impartiality, and of thus "shrinking away from indicated and necessary conclusions." 64

Needless to say, some investment of time is required when the staff organization functions as a group. But the time spent in conference is time gained for all, especially the department head, if the outcome is greater coherence and consistency in departmental planning and action.' Nor should one forget the fact that this kind of periodic group discussion tends to produce its own abbreviated form of oral communication. A great deal of business can be transacted in little time when the exchange of views is reduced to essentials, when few words suffice.

In general, departmental organization-federal, state, and localhas not been as hospitable to the group process in staff work as one might expect. Executives have too often confined themselves to drawing on existing staff units primarily for services inherent in their particular functions, and on the basis of a relatively formal relationship with the individual chiefs of these units. ${ }^{65}$ Yet it is clear that lack of initiative on the level of the departmental leadership merely magnifies proportionately the responsibility of each staff officer to develop the necessary contacts among the several staff units. He could not feel comfortable in his own work without considerable assurance that his projects and recommendations reflect a comprehensive approach so that all aspects will receive proper attention. The least he would have to do is make certain that any of his proposals placed before the department head represent the whole of what is known throughout the department and the best of the judgment available in any part of the organization. ${ }^{68}$

It might seem that in outlining the way a staff organization should function-which is another way of identifying its structure-we have slighted the substance of the staff job. Actually, form and sub-

63. Id. at 316.

64. Ibid.

65. The explanation lies in large part in the effects of our traditional ways of selecting department heads and their political associates. For the impact of this tradition on departmental management in federal administration, see MACMAHON AND MIILETT, FEDERAL AdMinistrators (1939).

66. For some incisive observations on "cross referencing" in staff work, see Appleby, Organizing Around the Head of a Large Federal Department, in 6 Puв. ADM. REv. 205, at 210 et seq. (1946). 
stance in this instance are very much the same. And there is little to be added to our earlier comments on the essence of all staff activity. ${ }^{67}$ In further elaboration, one could simply say that one of the foremost staff concerns is aiding the executive to see the forest rather than the trees. He must be enabled to dispose of the particular in the frame of the general. Or, as it has been stated with reference to secretaries in charge of federal departments, "the staff function is to help translate narrower, more specialized thinking and action into terms that will enable the secretary in his sphere and auxiliary to the presidential function to develop and maintain truly public policy and truly public administration." 68 Neither policy nor administration can be "truly public" when the specialized interest is allowed to override the general interest.

Assertion of the general point of view in the face of the specialized functional pressures arising from the various operating bureaus within a department takes up probably more than three-fourths of the total effort that goes into departmental management and program development. Left to themselves, these functional pressures could tear the department asunder. Frequently linked to interest groups and capable of mustering support in legislative committees, the operating bureaus find it hard to acknowledge the department-wide interest, just as departments in turn experience much difficulty in showing deference to the government-wide interest. ${ }^{69}$ It should not be assumed that staff work by itself can repulse these divisive pressures. Each such pressure has a basis in needs felt by the people-or by some people. Both from the angle of popular support and the principal personalities involved, the staff approach cannot ignore the fact that "the human equation must be taken into account in all policy recommendations." 70 On the other hand, the counterpressure of the general point of viewattempting to integrate the specialized pressures on the highest common denominator-is all the more urgent as an ally of departmental leadership.

67. See Part II supra.

68. Appleby, supra note 66, at 210.

69. The extent of an agency's or a bureau's support by interest groups obviously has much to do with the degree of control over administrative programs attempted by the legislature. As an illustration, the following exchange of questions and answers between a legislative committee and a federal agency, related to a request for funds, is instructive: "Q. Would a reduction be reflected in less service to the people?-A. Yes; it would. We would build up our backlog of claims to be processed. We have all these review cases where they are waiting for payment now. We were flooded with letters relating to payment of benefits under the amendments.- $Q$. Does the Brotherhood of Trainmen, the firemen, conductors, and so forth-are they interested in this?-A. Yes, sir; they check us very closely. They know how much we take in and pay out as well as the status of our work program.-Q. How about the railroad ownership? Are they interested in that?-A. Yes; they check that." Hearings Before House Committee on Appropriations on First Deficiency Appropriations Bill for 1947, 80th Cong., 1st Sess. 38 (1947).

70. Goldenweiser, supra note 56, at 317. 
Viewing problems and issues in their general rather than their particular meaning, in their general rather than their particular setting, calls for depth as well as breadth of inquiry. The particular usually is the immediate, arguing its own urgency. It is almost an attribute of time and circumstance. The general spans across time and circumstance. It has no pleader save for the mind that comprehends the general. Concern with the particular is prone to neglect the future, failing to notice what is ahead. The staff function, being the custodian of the general, must anticipate emerging events and trends. It must pull into current consideration the things still beyond the horizon. It must speculate, extend reconnaissance into the forward areas, reach. tentative findings about what is not yet but may be sooner or later.

And another point. Being dependent in large measure on the intellectual resources available within the entire department, staff units should never lose sight of the fact that in the last analysis it is their basic task to ease the administrative process. This is true of their relationships with both the departmental leadership and the operating bureaus and divisions. Sound staff work has the effect of protecting the executive against an uncontrolled onrush of matters that either should never be permitted to claim his precious time or could be disposed of effectively only upon sufficiently extensive groundwork. Without such groundwork few papers reaching his desk are actually ripe for his final action. Making them ripe for final action is known in military quarters as "completed staff work." 71 The idea of completed staff work, rightly understood, does not collide with the exploratory necessities of attaining fully considered determinations. Identification of problems and establishment of priorities for their solution is an activity inseparable from the executive function. Completed staff work does not mean that the staff officer should carry before the departmental leadership a finished solution to any problem freshly spotted. All he needs to come forth with is a recommendation on whether or not the problem should be tackled now or later and in what way. ${ }^{72}$ Easing the administrative process also entails selfrestraint on the part of staff officers in imposing unduly elaborate

71. As Webb (supra note 51) expresses it at 38, "Completed staff work should be envisioned by all concerned as the study of a given problem and the presentation of the solution thereof in such a manner as to require only approval or disapproval on the part of the commander concerned. It is the manifest duty of the staff officer to work out the details, regardless of their perplexity or irksomeness. This is not to infer that consultation with other staff personnel is not in order-it is. The execution of completed staff work dictates that the staff officer know his job. . . Completed staff work results in more work for the staff officers, but more time for the chief of staff to devote to broad policy."

72. Cf. Stone, Administrative Self-Improvement, in Elements of Public AdminISTRATION (Morstein Marx ed. 1946) 448, at 462 et seq. 
reporting requirements or managerial controls upon the operating bureaus of the department. In most jurisdictions, public administration drags along too heavy burdens of internal checks and safeguards. ${ }^{73}$ Good management calls for fewer rather than more of them.

Staff work, to repeat, throws great emphasis on mature understanding and insight. In all and everything he does, "the staff man must ponder and comprehend the full import and implications of the problems confronting his principals and of the policies designed to meet these problems." 74 One sin of omission may spoil the entire staff product. But sensitivity of intellect must not lead to timidity. When a departmental staff officer "begins to shape his opinions in accordance with what he thinks his principals want, his usefulness as a public servant is over." 75 A combination of tact and responsiveness in working relationships and fortitude in taking a stand on disagreeable facts is the foundation of a staff officer's value. Scarcely less important is his ability to subdue any yearning for the limelight and to stay in the wings of the stage of public affairs.

\section{IV}

- We started out by reviewing some evidence culled from official statements to show that administrative agencies look upon their law offices as staff establishments. ${ }^{76}$ Next we came to see that staff work under civilian auspices is marked to a high degree by a blending of different activities-such as planning and advising on the one hand, and assisting the executive by exercising part of his directive power on his behalf and even controlling certain operations on the other. ${ }^{77}$ With this caution, we proceeded to identify more specifically what appeared to be the essential characteristics of the staff approach, touching on attitude and mentality as well as organization and method. ${ }^{78}$ Now it is appropriate to make more explicit the special factors that impinge upon the staff role of the departmental law office, in particular the chief legal officer. Of course, as we talk of him, we must keep in mind that his own conduct and outlook are apt to set an example for the entire group of his professional subordinates-for better or for worse.

As was suggested at the outset, ${ }^{79}$ under the rule of law-so firmly woven into the matrix of Western civilization-public administration

73. See Part I supra.

74. Goldenweiser, supra note 56, at 316.

75. Id. at 317 .

76. See Part I supra.

77. See Part II supra.

78. See Part III supra.

79. See Part I sipra. 
in all of its manifestations is governed by legal canons. The mandate of an administrative agency is written out in law. The scope of an administrator's authority is defined by law. The range of his discretion is limited by law. There is perhaps some danger that the rule of law might transform itself at times into the rule of the lawyer. Certain it is, however, that the guardian of a department's legal interests stands near the center of the administrative process. ${ }^{80}$

Nor can there be much doubt that the chief legal officer in many an administrative agency ranks among the ablest and most influential officials. Whatever government service lacks in material incentives, it apparently has been able to attract a fair share of the best minds among those trained for the legal profession. ${ }^{81}$ Because of the relatively high caliber of agency lawyers, it might be expected that the law office operates as an important part of the departmental staff organization. Surprisingly, this is by no means the general rule.

What are the reasons? Some of the reasons have nothing to do with the institutional role of the law office. In quite a few administrative agencies one observes little that would suggest the existence of a true staff organization, if only in rudimentary form. In other agencies, the connection between the several staff units is reduced to intermittent working contacts that do not presuppose a common point of view. No less frequently, however, the ineffectual role of the departmental law office as a staff element is explained in its own self-limitations.

Some law offices, for instance, display a strong inclination to treat legal questions arising in the business of the department as abstract propositions not to be marred by the rough realities of the department's

80. Even under entirely different political auspices, the situation may not be basically different. With respect to Soviet Russia an authority points out that "Each government corporation has its general counsel who sits by the director and guides him through the intricacies of administration under the great volume of laws and instructions, which are issued by the Supreme Soviet, its Presidium, the Council of People's Commissars and the individual Commissariats. The general counsel usually represents the corporation in appearances before the state arbitration tribunals, although there have been attempts to require the director to appear in person. The socialist system of economy as it has been developed in the Soviet Union has found room for the legal adviser and lawyer, and many members of the legal profession are engaged in this manner." Hazard, The Lawyer Under Socialism, WIS. L. Rev. 90, 97 (1946). For Germany under Hitler, see Fraenkel, The DuAL State: A Contribution to the THEORY OF DictatoRshIP (1941) ; Kirchheimer, The Legal Order of National Socialism, 1 Stud. In Phrl. AND Soc. ScI. 456 (1941).

81. The evidence seems to support the conclusion that this is true not only in the United States, but also in England. As a well-informed observer with war-time experience in government work has put it, ". . I practised for ten years at the bar, and have held a University Chair [Professor of commercial and industrial law in the University of London] for half as long again. Based on this experience I have formed the view that there are in the Universities finer intellects, but they are much more specialized, and that while some of the outstanding figures at the bar have finer intellects also, the general standard there is appreciably lower than in the Civil Service." Chorley, Some Thoughts on the Civil Service, 3 AGENDA 109, 125 n. 6 (Nov. 1944). 
mission. These offices are happy to live their own day. An unkind critic may suspect that their whispered password is, "Hail the law, perish the department." The operating official, though the ultimate consumer of legal advice, is kept at arm's length. He is pointedly reminded that his problems are his own and have no standing in the eyes of the law.

Functional specialization typical of administrative agencies always tends to erect barriers between the groups of specialists. Law is no exception in this respect. A law office may find it more comforting to concentrate on its paper work in full enjoyment of its self-sufficiency than to go out of the way in order to make sure that its contribution to the administrative process actually meets the needs of managers and operators. An ivory-tower attitude may develop, demonstrated in a peculiar fastidiousness toward the uncouth demands of administrative necessity.

In the perspective of the legal mind, it may well appear selfevident that "administrators, bent upon specialized tasks, make unruly clients." 82 Having their own strange notions, they "are apt to insist that refined technology should outweigh the judgment of counsel familiar with the general processes and practice of the courts." 83 Indeed, "with constant friction and frequest disaster," they may seem ever ready to give point to the old proverb, "He who is his own lawyer has a fool for his client." 84 Yet it is altogether plain that the chief legal officer would accomplish next to nothing in commending his opinion to the administrator by telling him to take it or leave it. In fact it is one of the prime functions of the law office to fashion the legal tools needed for effective administration.

The functional isolation that may manifest itself in a deliberate withdrawal of the law office into the strictly "legal side of things" has more far-reaching effects upon an administrative agency than similar tendencies taking hold of other staff units. Except for budgeting and organization and methods work, legal analysis has no competitor among the other staff units in the extent to which it touches all operations and in the direct way of its influence. In every area of departmental business, in every bureau or division, the scope of authority and the propriety of means are questions arising time and again in the countless transactions that make up each major program. Increasing experience in the execution of a program, as a general rule, discloses opportunities for tightening or simplifying procedures, for obtaining better effects by using more efficient means, for reducing

82. Cummings AND MCF ARLAND, op. cit. supra note 10, at 509-510.

83. Ibid.

84. Ibid. 
avoidable inconveniences for the citizen in his role as the customer of the department. Changing circumstances may make it necessary to revise operating methods. Individual cases come up presenting legal points that yesterday still seemed to be settled but suddenly bring to the fore fresh doubts. At all of these junctures, the lawyer's diagnosis and prescription cannot fail to leave an imprint upon the way the department does its business. If he is satisfied with exercising his professional skill in sublime defiance of governmental "technology," his ministrations are likely to have a cramping effect upon his agency's institutional versatility.

Whatever its operating philosophy, the law office is in many ways drawn into the fundamental problems of departmental mandate and method. Each legislative session produces batches of bills proposing to add to, or to subtract from, this mandate, or changing it by direct or indirect reference. Whether or not the committee of the legislature considering these bills requests the views of the agency, opinions have to be prepared for the guidance of the administrator, and this is the job of the agency's law office. ${ }^{85}$ Then there is the ordinary run of questions with regard to the range of activities that the department may safely attempt to undertake under the statutes, and the alternatives it has in seeking to achieve its objectives most expeditiously. As the principal source of advice in these cardinal matters, the chief legal officer, not unnaturally, comes to be associated in the administrator's mind with nearly everything of real importance.

A predisposition on the part of the administrator to turn to his general counsel on all subjects uppermost in his mind greatly magnifies the latter's general influence. There is quite a bit of testimony to suggest that such a predisposition, of varying strength, is a rather common thing. The chief legal officer of a federal department recently remarked of his former agency head, with all the gracious restraint of phrase befitting the occasion, "I like to believe he asked me for advice on occasion on things that were not legal matters." 86 Or, as another highly qualified witness observed the other day, "As time passed, the Legal Division was called upon increasingly to participate in the legis-

85. On the municipal level, concern with pending legislation is usually left to the city attorney's office. This gives him a strategic position. "By the very nature of his position the city attorney tends to become a lobbyist and legislative representative. His familiarity with the law practically necessitates that he be the one to represent and protect the city's interests in the periodic sessions of the state legislature. One who attends these sessions will undoubtedly meet the lawyers of the League of Municipalities, representing a number of cities and their group interests, as well as staff members from the law offices of the larger cities and counties, who either stay on during the entire session or are in intermittent attendance." PFIFFNER, op. cit. supra note 6 , at 506 .

86. Hearings Before House Committee on Appropriations on Treasury Department Appropriation Bill for 1948, 80th Cong., 1st Sess. 884 (1947). 
lative process beyond the area of its own responsibilities." 87 On the other hand, when the exercise of the legal function displays a selfcontained and restrictive bent of mind, the law office in the end may hold a general veto power, deriving an unhealthy delight from asserting that "you can't do that."

By contrast, when acknowledging his staff role, the chief legal officer must detach himself as far as possible from the immediate aspects of his functional specialization. He does not win the intellectual freedom required for constructive staff work unless he views all of the activities of his office as one grand opportunity for helping the department gain a "truly public" motivation. This, we remember, ${ }^{88}$ is achieved only when the special pressures associated with particular functions are brought into a balance productive of coherent effort. Without counterpressure from the agency-wide level, the special pressures could not so be adjusted to one another as to bring about an adequate expression of the generality of departmental goals.

The needed point of view has been described eloquently by a former federal administrator of wide experience, who said, "I want a knowledge of what the law has undertaken to be in recent years-not an instrumentality by which people are pushed down or prevented from making the gains that an individual is entitled to, but the exercise of the entire society's expression of what it wants to do, through the medium of its elected representatives in the laws and its administration-the ways by which the complex problems of this civilization shall be met." 89 In this kind of orientation is rooted what for want of a better term may be called "sense of staff concert."

Sense of staff concert should induce the chief legal officer to take the initiative in bringing into the orbit of his knowledge as much as he can of all there is to be known about his agency. In his direction of the different phases of law business, he would fail to do a true staff job if he permitted neglect of relevant administrative opinion whereever it might be available in the department. He must attempt to grasp the mentality and the intricacies of operating the various functions entrusted to the bureaus and divisions. He must take a genuine interest in the business and the methodology of the other staff units.

Sense of staff concert would also make him an active agent in securing sufficient understanding for his own activities throughout the department, especially among his administrative colleagues. There is no good reason why operating officials, in ignorance of the facts, should

87. Fahy, The Lazeyer in Military Govermment of Germany, 15 DePT. of STATE Bull. 852, at 859 (1946).

88. See Part III supra.

89. Henderson, Opening Remarks, in A Manual of PRICE Control, op. cit. supra note 18 , at 2 . 
grumble about the "spirit of delay" 90 in which the lawyers interpose themselves in the departmental work processes. There is no good reason why misapprehensions should prevail about the "professional responsibility" 91 of the lawyers to make sure that administrative action does not exceed the powers granted by the legislature. Conversely, the give and take between legal work and general management is enhanced when everybody is equally indifferent to the "fiction that only lawyers can really understand the Constitution." ${ }^{2}$

Sense of staff concert, finally, will keep before the lawyer's mind his dual purpose. His is the task of helping both to "get things done and get them done in a way that is effective and does not bring undesirable repercussions upon the agency." 93 This dual purpose, necessarily, must be conceived in the light of the constitutional order. Public administration is service to the community. It cannot assume a neutral position toward its own effects within the community. Above all, it must always be profoundly mindful of the elementary liberties of the citizen.

The Administrative Procedure Act of 1946, against its own intentions, has probably deflected some of the axiomatic administrative concern for the rights of the individual. The act throws its weight on formalities of procedure rather than the promotion of conditions conducive to substantive justice. Over the inflexible uniformities of procedure, however, one should never forget the practical outcome of the particular case. After all, only a small fraction of collisions between-administrative authority and private rights ever reach the judicial forum. Most cases end with what review action takes place in the agency in response to informal complaint. As the trustee of the agency's legal estate, the law office is in a strategic position to raise the respect for justice in the treatment of the great run of inconspicuous small-scale disputes. This is a foremost duty under democratic government. ${ }^{94}$ It is a duty that requires vigorous articulation throughout the range of administrative operations. The more the chief legal officer fits himself into his staff role, the more closely does he approximate the ideal of serving his department as its conscience.

90. Leventhal, supra note 18 , at 290.

91. $I d$. at 287.

92. Corwin, The Posthumous Career of James Madison as Lawyer, 25 A. B. A. J. 821 (1939). This is an entertaining review of the documentary evidence on Madison's glory as a lawyer, showing that "the Father of the Constitution" was an informed layman but not a trained lawyer.

93. Leventhal, supra note 18 , at 291.

94. Cf. 6 Ors. Atty. Gen. 326, 333 (1854), quoted in Fairlie, Law Departments and Law Offices in American Governments, 36 MrcH. L. REv. 906, 913 (1938) ; Morstein Marx, supra note 17. 